\title{
GENOMIC DNA ISOLATION FROM SCROPHULARIEAE DRIED LEAVES USING A SIMPLE, HIGH-THROUGHPUT PROTOCOL
}

\author{
Mehrshid Riahi*, Melina Babaei and Farrokh Ghahremaninejad \\ Department of Plant Sciences, Faculty of Biological Sciences, \\ Kharazmi University, Tehran, Iran
}

Keywords: CTAB, DNA extraction, Scrophularia, Verbascum

\begin{abstract}
This communication described efficient DNA extraction from Scrophularia and Verbascum samples. Modified Murray and Thompson modified Cota-Sànchez method and Bioflux kit methods were applied for the extraction of DNA. Among the different methods, Bioflux kit Plant DNA extraction kit, coupled with some modification was the best for extraction of high molecular weight DNA as long as the extracted DNA is quantified with fluorescence-based methods.
\end{abstract}

The genera Verbascum L. with $\sim 360$ species and Scrophularia L. with $\sim 300$ species were placed in the tribe Scrophularieae based on molecular studies (Oxelman et al. 2005). The most crucial step for any molecular study is isolation of pure and high-quality of DNA. However, due to excessive presence of secondary metabolites, isolating pure DNA from plants is very difficult as compared to animals and microorganisms.

Mature leaves of Scrophularia and Verbascum contain a number of secondary metabolites in which the most important are the iridoid and phenylethanoid glycosides. Oxidation products of secondary metabolites covalently binds with DNA and make it resistant to restriction enzymes and give DNA a brown colour (Rawat et al. 2016).

Despite the development and use of several standard protocols for reproducibly extracting high quality DNA, it is quite impossible to develop a single isolation protocol which suits every plant species (Pirttilä et al. 2001, Riahi et al. 2009). In this study, four extraction techniques were compared using dry old leaves of Scrophularia and Verbascum, sometimes leaf samples over 60 years old. In the peresnt study the optimization of the protocol that provided the maximum yield of pure and high quality DNA is reported.

Fifteen species of Scrophularia and Verbascum were analyzed for their ability to yield DNA (Appendix 1). The dried leaves used came from herbarium specimens of various ages catalogued in herbarium of Tehran and Bingol University. Four methods of DNA extraction were evaluated.

DNA was extracted using a modified CTAB protocol (Murry and Thompson 1980). Extraction buffer consisted of CTAB (with $2 \%$ concentration), $1.4 \mathrm{M} \mathrm{NaCl}, 50 \mathrm{mM}$ EDTA with $\mathrm{pH} 8.0,100 \mathrm{mM}$ tris- $\mathrm{HCl}$ with $\mathrm{pH}$ 7.5. Immediately before use of EDTA, $0.4 \% \beta$-mercaptoethanol were added. Other solutions consisted of tris-EDTA (TE), chloroform: isoamyl alcohol (24:1) (Sigma Aldrich, Dorset, UK), $2.5 \mathrm{M}$ of sodium oxaloacetate, isopropanol, $10 \mathrm{mg} / \mathrm{ml}$ of RNase and 70 and $95 \% \mathrm{EtOH}$. For this protocol, $750 \mu \mathrm{l}$ of extraction buffer with a few amount of powdered herbarium leaves added to $1.5 \mathrm{ml}$ microtubes and spines well then were incubated for $1 \mathrm{hr}$ at $60^{\circ} \mathrm{C}$. Next $700 \mu \mathrm{l}$ of the chloroform: isoamyl alcohol (24:1) were added and centrifuged at 10,000 rpm for $15 \mathrm{~min}$. The aqueous phases were transferred to new tubes and $1: 3$ volume ice cold isopropanol were added and stored at $-30^{\circ} \mathrm{C}$ for $1 \mathrm{hr}$ and were further centrifuged at $10,000 \mathrm{rpm}$

*Author for correspondence: <mehrshidriahi@khu.ac.ir>. 
for $15 \mathrm{~min}$. Without disturbing the pellet, the supernatant was discarded. The pellets resuspended in $100-200 \mu \mathrm{l}$ of TE buffer. $1-2 \mu 110 \mathrm{mg} / \mathrm{ml}$ of RNase, 0.1 vol. $2.5 \mathrm{M}$ sodium oxaloacetate $(\mathrm{NaOAc})$ and 2 vol. ice-cold $95 \%$ ethanol were added respectively and stored at $-20^{\circ} \mathrm{C}$ for $30 \mathrm{~min}$ then centrifuged at $10,000 \mathrm{rpm}$ for $5 \mathrm{~min}$. The supernatant was discarded. The pellets were washed with $1 \mathrm{ml}$ of $70 \%$ ethanol. Then centrifuged at 10,000 rpm for $4 \mathrm{~min}$ and the ethanol were poured out. The pellets resuspended in $100-200 \mu \mathrm{l}$ of TE.

\section{Appendix 1. Species of Verbascum from herbariums of TUH (Tehran University, Tehran, Iran) and BUH (Bingol University, Bingol, Turkey). Each entry includes species, locality and voucher of herbarium specimens.}

\begin{tabular}{ll}
\hline Taxon & Source \\
\hline S. Crassicaulis Grau & Iran, yassuj to kakan; TUH, 1629, 1970 \\
S. atropatana Grossh. & Iran, Azarbayejan, Marand; TUH, 35551, 2013 \\
S. gaubae Bornm. & Iran, Mazandaran, Chalus; TUH, 29326, 2011 \\
S. frigida Boiss. & Iran, Khorassan, Sarakhs;35348, 2013 \\
S. deserti Del. & Iran, Baluchestan, Bazinan; TUH, 21540, 2009 \\
S. elbursensis Bornm & Iran, Mazandaran, Chalus; TUH, 2126, 1978 \\
S. amplexicaulis Benth. & Iran, Azarbayejan, Arasbaran; TUH, 35831, 2013 \\
V. agrimonifolium (C. Koch) Hub-Mor & Iran, Baluchestan, Bazinan; TUH, 21540, 2004 \\
V. alceoidesBoiss. \&Hausskn. & Iran, Mazandaran, Chalus; TUH, 29126, 2009 \\
V. assurense Bornm. \& Hand.-Mazz. & Iran, Azarbayejan, Arasbaran; TUH, 35831, 2010 \\
V. aucheri (Boiss.) Hub.-Mor & Iran, Azarbayjan; TUH, 25143, 2003 \\
V. austroiranicum Hub.-Mor. & Iran, Kerman, Kuhpaye; TUH, 28547, 2007 \\
V. birandianum Hub.-Mor. & Turkey, Bitlis; BUH,1033, 2001 \\
V. pyramidatum M. B. & Turkey, Bitlis; BUH,1031, 2001 \\
V. helianthemoides Hub.-Mor. & Turkey, Kayseri; BUH, 4439, 2006 \\
\hline
\end{tabular}

Modified Cota-Sanchez et al. (2004) method was used for the extraction buffer of modified Cota-Sànchez which was consisted of CTAB (with $2 \%$ concentration), $1.4 \mathrm{M} \mathrm{NaCl}, 20 \mathrm{mM}$ EDTA with $\mathrm{pH} 8.0,100 \mathrm{mM}$ tris- $\mathrm{HCl}$ with $\mathrm{pH}$ 7.5. Immediately before use of EDTA, $1 \% \beta-$ mercaptoethanol was added. Other solutions consisted of tris-EDTA (TE): $10 \mathrm{mM}$ tris- HCL and $1 \mathrm{mM}$ EDTA at pH 8.0, chloroform: isoamyl alcohol (24:1), chilled Isopropanol, and $70 \% \mathrm{EtOH}$.

In this protocol, $\mathrm{CTAB}$ was preheated to $65^{\circ} \mathrm{C}$. Then, $800 \mu \mathrm{l}$ of CTAB buffer and a few amount of powdered herbarium leaves added to $1.5 \mathrm{ml}$ microtubes and spines well. The samples were incubated for $15 \mathrm{~min}$ at $65^{\circ} \mathrm{C}$. The Microtubes were kept on ice in order to cool down to the room temperature. Then $750 \mu \mathrm{l}$ of the CIA were added and 50 times inverted. After that the Microtubes centrifuged at 10,000 rpm for $15 \mathrm{~min}$. The supernatant was transferred to new tubes and extraction steps were repeated. The supernatant was transferred to new tube with 0.7 of microtube volume ice cold isopropanol and 10 times inverted gently. Afterward, the tubes centrifuged at 10,000 rpm for $15 \mathrm{~min}$. When the pellets of samples were clear, without disturbing the pellets, the supernatants were discarded but when the pellets were above gelatinous materials, all of the supernatants were removed but the gelatinous materials and the pellets left intact. Next the pellets were washed with $1 \mathrm{ml}$ of $70 \%$ ethanol and centrifuged at 10,000 rpm for $10 \mathrm{~min}$ and the ethanols were poured out. This step was repeated. The pellets were dried and resuspended in $20-50 \mu \mathrm{l}$ of TE buffer and incubated at $37^{\circ} \mathrm{C}$ for $30 \mathrm{~min}$. 
BioFlux plant DNA extraction kit (Bioer Technology Co. Ltd.) method uses silica-gelmembrane technology and simple spin procedures to isolate high-quality DNA. The kit consisted of the LP, DA, P binding, washing and elution buffers.

Modified Bioflux plant DNA extraction Kit was used in this method. The protocol was modified from the manufacturer's instructions in that the dried plant leaves were stored at $-80^{\circ} \mathrm{C}$ overnight prior to homogenization by Tissue Processor System (Qiagen, Modified- BioFlux Plant Genomic DNA Extraction Kit). Additionally, $50 \mathrm{mg}$ (instead of $100 \mathrm{mg}$ ) of tissue powder were transferred to a 1.5 microcentrifuge tube and $700 \mu \mathrm{l}$ (instead of $450 \mu \mathrm{l}$ ) LP buffer was added. The tubes incubated at $65^{\circ} \mathrm{C}$ for $45 \mathrm{~min}$ instead of $30 \mathrm{~min}$ and finally $50 \mu \mathrm{l}$ (instead of $200 \mu \mathrm{l}$ ) elution buffer was added. The purified DNA kept at room temperature for $1 \mathrm{hr}$ and in $4^{\circ} \mathrm{C}$ for $24 \mathrm{hrs}$ and then stored at $-20^{\circ} \mathrm{C}$.

To check the purity, DNA was obtained from four procedures was separated on $0.8 \%(\mathrm{w} / \mathrm{v})$ agarose gel prepared using 1X TAE buffer and visualized on Gel Documentation system (Herolab, Germany). DNA was quantified using biospectrophotometer (Eppendorf, Germany) at a wavelength of 260 and $280 \mathrm{~nm}$. Purity was checked from ratio of absorbance 260/280. Then DNA was qualified with PCR amplification of using 2 molecular markers (nrDNA ITS4 and trnS (GCU)-trnG (UCC) (trnS/G).

Extracted DNA obtained from all 4 methods were evaluated based on color, the quality of DNA, the ratio of spectrophotometry, concentration of DNA and the bands obtained from PCR on agarose gel (Table 1). Test results indicated the superiority of modified extraction kit in Scrophularia and Verbascum specimens. DNA extracted using commercially available kit contained some level of polyphenolics impurities (Fig. 1. Lane 1 - 6), low level of A260/280 ratio and modicum concentration (Table 1). The spectrophotometric measurements indicated that the most of the samples using protocol 1 and 2 yielded no DNA or DNA with a lot of contaminants, poor yield and A260/280 value less than 1.6 which did not meet optimal limit of 1.8 (Fig. 2.) as they were unable to remove the secondary metabolites of the samples as they were the most important factor inhibiting the PCR (Pirttilä et al. 2001). The amplification of these samples with highest amount of contaminants was not successful. Extracted DNA with these two protocols also contained residual CTAB in samples which was founded by spectrophotometry and agarose gel. Residual CTAB in samples can lead to an over estimation of the yield in the photometric measurements (Drábková et al. 2002). The protocol 1 and 2 require more time and advanced equipments. In order to yield DNA suitable for PCR, some modifications in the kit extraction protocol that produced high quality DNA from all species (Fig. 1. Lane 7 - 10) were made. The modification involved freezing tissue prior to homogenization to purge polyphenols as well as the use of a lower plant powder $(50 \mathrm{mg}$ instead of $100 \mathrm{mg}$ ) to reduce secondary metabolic concentration (Lodhi et al. 1994) and a higher amount of LP buffer (700 $\mu$ l instead of $450 \mu \mathrm{l})$ longer incubation time for this step (30 min instead of $15 \mathrm{~min}$ ) ) for better lyses and a lower amount of elution buffer $(50 \mu \mathrm{l}$ instead of $200 \mu \mathrm{l})$ to prevent decrease in DNA concentration with longer time for this buffer ( $5 \mathrm{~min}$ instead of $1 \mathrm{~min}$ ).

Although the expected DNA yield from smaller sample amount should be lower, the possibilities for contaminants to coprecipitate with DNA are also lower, due to their saturation concentration during precipitation is less likely reached or exceeded (Pirttilä et al. 2001). Furthermore, the extracted DNA was kept at room temperature for $1 \mathrm{hr}$ and in $4^{\circ} \mathrm{C}$ for $24 \mathrm{hrs}$ in order to reduce RNA concentration and then stored at $-20^{\circ} \mathrm{C}$. The extracted DNA was substantially free of contaminants based upon an A260/280 ratio of 1.8 and its privation of coloration, which indicates unadulterated genomic DNA (Brown 1995). The extracted DNA was convenient for PCR which remained usable for at least 2 years when stored at $-20^{\circ} \mathrm{C}$. A reduction 
Table 1. Evaluation of samples extracted using protocols A (modified Murray and Thompson, 1980), B (modified Cota- Sánchez et al. 2006), C (Bioflux plant extraction kit) and D (modified Biofluxplant extraction kit) based on extraction color, quality of DNA, Cc (ng/ul), A260/280 and PCR amplification.

\begin{tabular}{|c|c|c|c|c|c|}
\hline \multirow[t]{2}{*}{$\begin{array}{l}\text { Species of Verbascum } \\
\text { and Scrophularia }\end{array}$} & $\begin{array}{l}\text { Extraction } \\
\text { color }^{\mathrm{A}}\end{array}$ & $\begin{array}{l}\text { Quality of } \\
\text { DNA }^{B}\end{array}$ & $\mathrm{Cc}(\mathrm{ng} / \mathrm{ul})^{\mathrm{C}}$ & $\mathrm{A}_{260 / 280} \mathrm{D}$ & $\mathrm{PCR}^{\mathrm{E}}$ \\
\hline & $\begin{array}{c}\text { Based on } \\
\text { Protocol A/ } \\
\text { B/C/D }\end{array}$ & $\begin{array}{c}\text { Based on } \\
\text { Protocol A/ } \\
\text { B/C/D }\end{array}$ & $\begin{array}{c}\text { Based on } \\
\text { Protocol A/ } \\
\text { B/C/D }\end{array}$ & $\begin{array}{c}\text { Based on } \\
\text { Protocol A/ } \\
\text { B/C/D }\end{array}$ & $\begin{array}{c}\text { Based on } \\
\text { Protocol A/ } \\
\text { B/C/D }\end{array}$ \\
\hline S. crassicaulis & $3 / 3 / 1 / 1$ & $3 / 3 / 2 / 2$ & $3 / 3 / 3 / 3$ & $3 / 3 / 2 / 1$ & $2 / 2 / 2 / 1$ \\
\hline S. atropatana & $2 / 2 / 1 / 1$ & $3 / 3 / 1 / 1$ & $2 / / 22 / 1$ & $2 / 3 / 1 / 1$ & $2 / 2 / 1 / 2$ \\
\hline S. gaubae & $2 / 2 / 2 / 1$ & $3 / 3 / 2 / 1$ & $2 / 3 / 3 / 2$ & $3 / 3 / 2 / 1$ & $2 / 2 / 1 / 1$ \\
\hline S. frigida & $1 / 1 / 2 / 1$ & $3 / 3 / 2 / 1$ & $3 / 3 / 3 / 2$ & $3 / 2 / 2 / 1$ & $2 / 2 / 1 / 1$ \\
\hline S. deserti & $3 / 2 / 2 / 1$ & $3 / 2 / 2 / 1$ & $3 / 3 / 2 / 2$ & $2 / 2 / 2 / 1$ & $2 / 3 / 1 / 1$ \\
\hline S. elbursensis & $1 / 2 / 1 / 1$ & $1 / 1 / 2 / 2$ & $1 / 1 / 2 / 2$ & $1 / 1 / 2 / 1$ & $2 / 1 / 2 / 2$ \\
\hline S. amplexicaulis & $1 / 1 / 1 / 1$ & $1 / 1 / 1 / 1$ & $1 / 2 / 1 / 1$ & $1 / 2 / 1 / 1$ & $2 / 2 / 1 / 1$ \\
\hline V. agrimonifolium & $3 / 3 / 1 / 1$ & $3 / 2 / 1 / 1$ & $3 / 2 / 3 / 1$ & $3 / 3 / 1 / 1$ & $2 / 2 / 1 / 1$ \\
\hline V. alceoides & $3 / 3 / 1 / 1$ & $3 / 3 / 1 / 1$ & $3 / 3 / 1 / 1$ & $3 / 3 / 1 / 1$ & $2 / 2 / 1 / 1$ \\
\hline V. assurense & $3 / 3 / 1 / 1$ & $\mathrm{NA} / 3 / 2 / 1$ & $3 / 2 / \mathrm{NA} / 2$ & $3 / 3 / 1 / 1$ & $2 / 2 / 2 / 1$ \\
\hline V. aucheri & $3 / 3 / 1 / 1$ & $\mathrm{NA} / 3 / 1 / 1$ & $3 / 3 / 1 / 1$ & $3 / 3 / 1 / 1$ & $2 / 3 / 1$ \\
\hline V. austroiranicum & $3 / 2 / 1 / 1$ & $3 / 3 / 1 / 1$ & $3 / 3 / 2 / 1$ & $3 / 3 / 3 / 1$ & $2 / 1 / 1 / 1$ \\
\hline V. birandianum & $3 / 3 / 1 / 2$ & $3 / 2 / 2 / 2$ & $3 / 2 / 2 / 2$ & $3 / 2 / 1 / 2$ & $2 / 1 / 3 / 2$ \\
\hline V. pyramidatum & $3 / 3 / 1 / 2$ & $3 / 3 / 2 / 2$ & $3 / 3 / 3 / 2$ & $3 / 3 / 2 / 2$ & $2 / 3 / 2 / 2$ \\
\hline$V$. helianthemoides & $3 / 3 / 1 / 2$ & $3 / 3 / 2 / 2$ & $3 / 3 / 2 / 2$ & $3 / 3 / 3 / 2$ & $2 / 2 / 3 / 2$ \\
\hline
\end{tabular}

A: 1 = Colorless; 2 = colored (yellowish); 3 = Brown (dark); NA = Not applicable. B: 1 = Slightly degraded; $2=$ Moderate degraded; $3=$ Highly degraded. C: $1=200 \mathrm{ng} / \mu \mathrm{L} \leq \mathrm{Cc} ; 2=50 \mathrm{ng} / \mu \mathrm{l} \leq \mathrm{Cc}<200 \mathrm{ng} / \mu \mathrm{l} ; 3=\mathrm{Cc}$ $<50$ ng/Ml. D: $1=1.8 \leq \mathrm{A} \leq 1.89 ; 2=1.9 \leq \mathrm{A} \leq 2 ; 3=1.5 \leq \mathrm{A} \leq 1.79$. E: PCR amplification of trnS/G: $1=$ exhibited specific amplification; $2=$ No amplification.

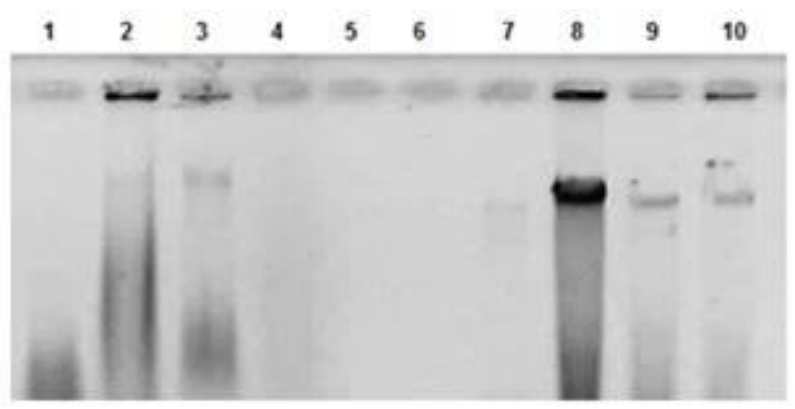

Fig. 1. DNA of the different plant species on $0.8 \%$ agarose gels, obtained using protocols 3 and 4 . Total DNA extracted using protocol 3. Lane $1=V$. agrimonifolium; lane $2=S$. amplexicaulis; lane $3=V$. alceoides; lane $4=V$. aucheri; lane $5=V$. austroiranicum; lane $6=V$. birandianum. Total DNA extracted using protocol D. Lane $7=V$. birandianum; lane $8=V$. aucheri $;$ lane $9=$ S.crassicaulis $;$ lane $10=V$. helianthemoides . 


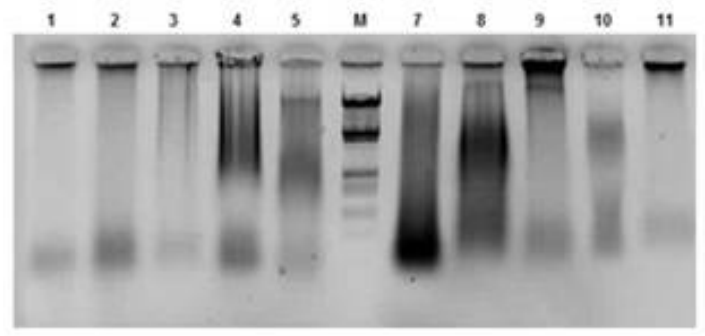

Fig. 2. DNA of the different plant species on $0.8 \%$ agarose gels, obtained using protocols 1 and 2. Total DNA extracted using protocol 1 . Lane $1=S$. frigida; lane $2=V$. alceoides; lane $3=V$. assurense $;$ lane $4=S$. atropatana $;$ lane $5=V$. austroiranicum; lane $6=$ Molecular Marker B. Total DNA extracted using protocol 2. Lane $7=V$. assurense $;$ lane $8=$ S. frigida; lane $9=V$. birandianum; lane $10=S$. deserti; lane $11=V$. helianthemoides .

in contaminating metabolites (such as PCR inhibitors) in the sample mixtures, suitable quality of DNA for PCR amplification and reduced DNA extraction time were important characteristic of the modified kit extraction protocol compared to other protocols (Fig. 1-2 and Table 1). Based on the peresent investigation, the best method for extraction of high molecular weight DNA from old dried leaves of Scrophularia and Verbascum was the Bio Flux Plant DNA extraction Kit, coupled with some modification.

\section{Acknowledgments}

Thanks to the reviewers for their constructive comments and suggestions.

\section{References}

Brown TA 1995. Gene cloning: An introduction Brown. No. PA 575.

Cota-Sánchez JH, Remarchuk K and Ubayasena K 2004. Ready-to-use DNA extracted with a CTAB method adapted for herbarium specimens and mucilaginous plant tissue. Plant Mol. Biol. Rep. 24: 161-167.

Drábková L, Kirschner J and Vlcek C 2002. Comparison of seven DNA extraction and amplification protocols in historical herbarium specimens of Juncaceae. Plant Mol. Biol. Rep. 20: 161-175.

Lodhi MA, Ye GN, Weeden NF and Reisch BI 1994. A simple and efficient method of DNA extraction from grapevine cultivars and Vitis species and Ampelopsis. Plant Mol. Biol. Report. 12: 6-13.

Murray MG and Thompson WF 1980. Rapid isolation of high molecular weight plant DNA. Nucleic Acids Research 8: 4321-4326.

Oxelman B, Kornhall P, Olmstead RG, and Bremer B 2005. Further disintegration of Scrophulariaceae. Taxon. 54: 411-425.

Pirttilä AM, Hirsikorpi M, Kämäräinen T, Jaakola L and Hohtola A 2001. DNA isolation methods for medicinal and aromatic plants. Plant Mol. Boil. Rep. 19: 273-273.

Porebski S, Bailey LG and Baum BR 1997. Modification of a CTAB DNA extraction protocol for plants containing high polysaccharide and polyphenol components. Plant Mol. Boil. Rep. 15: 8-15.

Rawat S, Joshi G, Annapurna D, Arunkumar AN and Karaba NN 2016. Standardization of DNA extraction method from mature dried leaves and ISSR-PCR conditions for Meliadubia Cav.-A fast growing multipurpose tree species. A JPS. 7: 437.

Riahi M, Zarre S, Maassoumi AA, Attar F and Kazempour OS 2009. An inexpensive and rapid method for extracting papilionoid genomic DNA from herbarium specimens. GMR. 9(3): 1334-1342.

Tatlı II, Schuhly W and Akdemir ZS 2007. Secondary metabolites from bioactive methanolic extract of Verbascum pycnostachyum Boiss. and Helder flowers. J. Faculty of Pharmacy. 27: 23-32. 